\title{
Laboratory and field evaluation of subsoiler- cum -vermicompost and soil amendments applicator
}

J.P. Singh and T.C. Thakur

Received : 05.01.2018; Revised : 09.03.2018; Accepted : 21.03.2018

See end of the Paper for authors' affiliation

Correspondence to :

\section{J.P. Singh}

Division of Agricultural

Engineering, Sher-e-Kashmir

University of Agricultural

Sciences and Technology,

Jammu ( $J$ and $K$ ) India

Email : jai12123@rediffmail.

com
-ABSTRACT : A tractor drawn 'subsoiler cum vermicompost and soil amendments applicator' was design and developed to examine the basic concept for placement of organic manures and inorganic fertilizers in subsoil at different depth upto $400 \mathrm{~mm}$. The developed machine was evaluated in laboratory for discharge rate and distribution pattern of different organic manures viz., vermicompost, pressmud and FYM at three moisture states and soil amendments i.e. gypsum, lime, cement and rice husk. Prior to laboratory testing of the machine, the physical properties of materials were studied. The machine was also tested under field condition on the basis of changes in dry bulk density, specific draft and wheel slippage at 250, 300, 350 and $400 \mathrm{~mm}$ depths of operation. The results revealed that the bulk density was uniform throughout the soil profile after operating at 400 mm depth. The bulk density reduced to a maximum of 13.88 per cent. The specific draft for $400 \mathrm{~mm}$ depth of operation was found lower by 33.26 per cent than that at $250 \mathrm{~mm}$ depth. Whereas, the wheel slippage was found to a maximum of 21.07 per cent at the draft of $12.20 \mathrm{kN}$ for $400 \mathrm{~mm}$ depth of operation. The results obtained during performance evaluation of developed machine on response of mustard crop have clearly revealed the advantage of subsoiling and deep placement of organic and inorganic fertilizers in terms of substantial increase in yield parameters.

— KEY WORDS : Field evaluation, Subsoiler- cum -vermicompost, Soil amendments applicator

- HOW TO CITE THIS PAPER : Singh, J.P. and Thakur, T.C. (2018). Laboratory and field evaluation of subsoiler- cum -vermicompost and soil amendments applicator. Internat. J. Agric. Engg., 11(1) : 233-243, DOI: 10.15740/HAS/IJAE/11.1/233-243. 